\title{
Ewondo Language
}

National Cancer Institute

\section{Source}

National Cancer Institute. Ewondo Language. NCI Thesaurus. Code C153913.

A Niger-Congo language spoken by the Ewondo people of Cameroon. 